\title{
SINOP MILLET MEKTEPLERI (1928-1935)
}

\author{
SINOP PUBLIC SCHOOLS (1928-1935)
}

\begin{abstract}
Yücel NAMAL*
Geliş Tarihi/Received:02.09.2019

Kabul Tarihi/Accepted: 05.12.2019

NAMAL, Yücel, (2020), "Sinop Millet Mektepleri (1928-1935)”, Belgi Dergisi, C.2, S.19, Pamukkale Üniversitesi Atatürk ilkeleri ve İnkılâp Tarihi Araştırma ve Uygulama Merkezi Yayını, Kış 2020/ı, ss. 1766-1785.
\end{abstract}

\section{Öz}

Türkiye Cumhuriyeti Devleti'nin kuruluşundan sonra gerçekleşen önemli inkılâplardan biri harf inkılâbıdır. 1 Kasım 1928 tarihinde yapılan harf inkılâbının ardından 1 Ocak 1929'da okuma yazmayı yaygınlaştırmak amacıyla bir halk eğitimi kurumu olan Millet Mektepleri kurulmuştur. Millet Mektepleri aracılığıyla halkın yeni harfleri hızla öğrenmesi sağlanmıştır. Bunun dışında Millet Mektepleri günlük hayat ile ilgili ve vatandaşıı bilgilerinin öğretilmesinde de etkili olmuştur. Millet Mektepleri bütün illerde, ilçelerde ve köylerde (A) ve (B) dershaneleri şeklinde teşkilatlanmıştır. Millet Mektepleri (A) dershanelerinde ne eski ne de yeni harfleri bilmeyenler alfabe, kıraat, yazı ve imla derslerini görmüştür. (B) dershanelerinde ise (A) dershanelerinden mezun olanlar başta hesap, sağlık ve yurt bilgisi gibi vatandaşlık dersleri yanında kıraat ve tahrir dersleri de almıştır. Böylece Cumhuriyetin halka doğru hareketinin bir örneği olan Millet Mektepleri halkı aydınlatarak tebaadan vatandaşlığa geçişte önemli bir rol üstlenmiştir.

Bu çalışmamızda yurt genelindeki okuma yazma seferberliğinin Sinop’a yansıması ve Millet Mekteplerinin buradaki teşkilatlanması ele alınmaya çalışılmıştır. Çalışmamızda 1928-1935 yılları arasında Sinop'taki Millet Mektebi dershanesi, öğretmeni ve öğrencilerinin durumu cinsiyetleri açısından ele alınmıştır. Ayrıca Millet Mekteplerinde eğitim gören öğrencilerin başarı ve başarısızlık durumu da $A$ ve $B$ dershaneleri çerçevesinde ortaya konulmuştur. Bu istatistikî verilerle elde edilen sonuçla Sinop'ta kurulan Millet Mekteplerinin yurt geneliyle karşılaştırması yapılarak faaliyetlerinin başarısı değerlendirilmiştir. Çalışmamızda başta Başbakanlık Cumhuriyet Arşivi (BCA) olmak üzere Başvekâlet İstatistik Umum Müdürlüğü tarafindan yayımlanan istatistikler ve konuyla ilgili diğer yayınlardan da faydalanılmıştır.

Anahtar Kelimeler: Türkiye Cumhuriyeti, Millet Mektepleri, Sinop, Eğitim, Harf Inkılâbı.

\begin{abstract}
One of the most important revolutions that took place after the establishment of Turkish Republic is Alphabet Revolution. After Alphabet Revolution on November 1, 1929, a public education institution, School of Public Education was established in order to popularize reading and writing. It was ensured that the people were able to learn new letters rapidly through the National Schools. Additionally, Public Schools were also effective in teaching everyday life and citizenship knowledge. Public Schools were organized as (A) and (B) classes in all provinces, districts and villages. In Public Schools $(A)$ courses, those who know neither old nor new letters were taught alphabet, reading, writing and spelling. In (B) courses, those students who graduated from (A) courses were educated in account, health and citizenship such as national knowledge, in addition to reading and writing. Thus, Public Schools, which are an example of the movement of the Republic towards people, have played an important role in transition of citizens from citizen to citizenship by enlightening the people.
\end{abstract}

*Bülent Ecevit Üniversitesi, Fen-Edebiyat Fakültesi Tarih Bölümü, ZONGULDAK, yucelnamal@hotmail.com, (orcid.org/0000-0002-8074-0134) 
In this paper, the reflection of the literacy mobilization across the country to Sinop and the organization of the Public Schools in this city were discussed. In our study, between the years 1928 and 1935 the status of Public Schools, teachers and students in Sinop were discussed in terms of gender. Furthermore, the success and failure level of the students, who were educated at Public Schools, were also put forward within the framework of A and B courses. With the results obtained from these statistical data, Public Schools established in Sinop were compared to the other Public Schools nationwide and the success of the activities of these schools was examined. In our study, mainly Prime Ministry Republic Archive (BCA), the statistics published by the Directorate General of Statistics and other publications were used.

Keywords: Turkish Republic , Public Schools, Sinop, Education, Alphabet Revolution.

\section{GiRiş}

Tarihi başlatan "yazı" bir zeka ürünü olduğu için insanları hayvanlardan ayıran bir özellik olarak karşımıza çıkmaktadır ${ }^{1}$ Y Yazının M.Ö. 3000'lerde bulunmasından sonra Türkler sırayla Göktürk, Uygur, Süryani ve Arap alfabelerini kullanmışlardır². Türklerin Uygur alfabesinden sonra en uzun süre kullandığı alfabe $X$. yüzyıldan sonra kullanılmaya başlanan $^{3}$ ve XVI. yüzyılda son şeklini alan Arap alfabesi olmuştur ${ }^{4}$. Ancak XIX. yüzyılın ortalarında matbaa, basın ve telgraf gibi teknoloji ve iletişim araçlarının gelişmesiyle ve yaygınlaşmasıyla yazı önemli bir unsur olarak ön plana çıkmıştır. Bu durum alfabe ıslahının gerekliliğini doğurmuş ve basında alfabe sorununu zaman zaman gündeme getirmiştir. $\mathrm{Bu}$ bağlamda Osmanlı Devleti'nin Latin harfleriyle tanışması III. Selim döneminde Avrupa'ya sürekli elçiliklerde görev yapanların yabancı dil öğrenmeye başlamasıyla olmuşsa da ${ }^{5}$ Tercüme Odasının kurularak burada Fransızcanın etkili olması ve matbaada İslam dışı eserlerin basılması da büyük bir katkı sağlamıştır ${ }^{6}$. Tanzimat'la birlikte dilde sadeleşme düşüncesi yaygınlık kazanmış; Şinasi, Namık Kemal, Ahmet Mithat Efendi, Ziya Paşa, Abdülhak Hamit ve Muallim Naci bu düşüncenin savunucuları olmuştur ${ }^{7}$. Ancak Servet-i Fünun edebiyatının önde gelen isimlerinden bazıları sade dilin edebiyatı öldürebileceği iddiasıyla bu anlayışa karşı çıkmışlardır . Fakat Arap harflerinin Türkçe sesleri tam olarak karşılayamaması ve öğrenilmesindeki zorluklar karşısında bu sorunu çözmeye yönelik ilk gerçekçi girişim Münif Paşadan gelmiştir. 12 Mayıs 1862'de kurucusu olduğu Cemiyet-i İlmiye-i Osmaniye'de verdiği konferansta Arap harfleriyle kitap basımının zorluklarından bahsetmiştir. Bu zorluğun giderilebilmesi için ya sesli harflerin olduğu herekeli yazım tarzı ${ }^{9}$ ya da her harfin ayrı bir biçimde yazıldığı huruf-ı munfasıla yöntemi tercih edilmelidir. Ancak Münif Paşa, huruf-ı munfasıladan yana olup Latin harflerinin alınmasını gündeme getirmemiştir $^{10}$. Latin harflerinin alınması konusunu ilk olarak gündeme getiren Azerbaycanlı Mirza Fethali Ahundzade'dir. Ahundzade'nin 1863 yılında Sadrazam Fuad Paşa'ya sunduğu raporunun Cemiyet-i İlmiye-i Osmaniye tarafından kabul edilmemesi

1 Füruzan Kınal, “Çivi Yazısının Doğuşu ve Gelişmesi”, Tarih Araştırmaları Dergisi, Sayı: 12, 1969 , s. 1.

2 Şinasi Tekin, Türk Dünyası El Kitabı, Cilt: 2, Türk Kültürünü Araştırma Enstitüsü Yayınları, Ankara 1992, s. 72.

3 Hatice Şirin, "Türklerde Alfabe ve Kimlik", Türkler, Cilt. 3, Semih Ofset, Ankara, 2002, s. 745.

4 Mustafa Canpolat, "Arap Yazılı Türk Alfabesinin Gelişmesi”, Harf Devriminin 50. Yılı Sempozyumu, Türk Tarih Kurumu yayınları, Ankara, 1991, s. 50.

5 Bilal N. Şimşir, Türk Yazı Devrimi, Türk Tarih Kurumu Yayınları, Ankara, 1992, s. 31.

6 Ejder Okumuş, "Tanzimat’ın Dili”, Türkler, Cilt. 15, Semih Ofset, Ankara, 2002, s. 140-141.

7 Musa Duman, "Yenileşme Dönemi Türk Dili”, Türkler, Cilt. 15, Semih Ofset, Ankara, 2002, s. 112.

8 Sinan Ateş, Yücel Namal, Muhibbe Erdoğan, Harf İnkıâbı ve Millet Mektepleri (1928-1935): Zonguldak Örneği, Ötüken Yayınları, İstanbul, 2019, s. 18.

9 Bilal N. Şimşir, a.g.e., s. 20.

10 Şimşir, a.g.e., s. 21. 
üzerine Arap harflerinin yerine Latin harflerinin alınması gerektiğini ifade etmiştir ${ }^{11}$. Ayrıca Ahundzade alfabe değişikliğine dinin bir engel oluşturmayacağını da vurgulamıştır.

II. Meşrutiyet döneminde de bu konu canlılığını korumuş ve bir resmi bir de gayri resmi çalışma yapılmıştır. Resmi çalışma 1909'da Maarif Nezaretinde kurulan İmla Komisyonu ile gayri resmi çalışma ise 1911 'de Recaizade Mahmut Ekrem'in kurduğu "Islah-ı Huruf Cemiyeti"nde yapılmıştır. Ardından 1912'nin başında birçok eseri bulunan Müşir Gazi Ahmet Muhtar Paşa'nın bulunduğu "Islah-ı Huruf Encümeni" adında yeni bir dernek kurulmuştur $^{12}$. Görüldüğü üzere II. Meşrutiyet döneminde alfabe tartışmalarında iki görüş hâkim olmuştur. Birincisi Arap harfleri yerine Latin harflerini kullanmak, ikincisi ise Arap harflerinin Türkçe yazı diline daha uygun bir hale getirilmesiydi.

Osmanlı Devletinde harf ıslahı konusuyla ilgilenen son isim Enver Paşa olmuştur. Her sessiz harfin yanına bir sesli harf koyarak oluşturulan bu yeni yazı "Enveri yazı, ordu elifbası" gibi isimlerle anılmıştır. Bu yazıyı ${ }^{13}$ askerlere öğretmek için küçük kitapçıklar dahi hazırlanmıştır. Ancak I. Dünya Savaşı'nın başlamasıyla birlikte ordudan gelen şikâyetler üzerine bu yazıdan da vazgeçilmiştir ${ }^{14}$. Buna karşın Irak'ta bulunan bazı Türk birliklerinin Alman imlasını kullanarak ihtiyaç listeleri hazırladıkları görülmüştür ${ }^{15}$. Latin harflerini savunanlar yani "Latinciler" olarak adlandırılanlar arasında Ittihat ve Terakki Partisinin kurucularından İbrahim Temo, Celan Nuri, Kılıçzade Hakkı, Abdullah Cevdet, Musullu Dr. Davut ve Hüseyin Cahit Yalçın bulunuyordu. Buna karşın latin harflerini savunanların yanı sıra, buna karşı olanlarda bulunuyordu ${ }^{16}$. Latin harflerinin karşısında olan isimlerden biriside Kazım Karabekir Paşa idi. İzmir İktisat Kongresinde yeni Türkiye'nin ekonomik durumunun yanı sıra İzmirli Nazmi ve iki arkadaşı tarafından Latin harflerinin kabulü için bir önerge verilmişse de kongre başkanı Kazım Karabekir tarafından reddedilmiştir ${ }^{17}$. Karabekir'e göre harf inkılâbının imkânsız olduğunun en büyük ispatı Arnavutların Latin harflerine geçmek istemelerindeki başarısızlıktı. Ayrıca Karabekir, Fransız harflerinin çok karışık olmasından dolayı yazılacak olan eserlerin okunamayacağını ve bunun da Avrupa'nın elinde bir silah olacağı düşüncesindeydi ${ }^{18}$.

Bu konu zaman zaman TBMM içerisinde de tartışmalara neden olmuştur. Bu bağlamda milletvekili Şükrü Saraçoğlu TBMM'de, Milli Eğitim Bakanını eleştirirken ülkede okuma yazma bilenlerin azlığının sebebi olarak Arap harflerini göstermesi üzerine mecliste tartışma çıkmıştır. Bu tartışmayı da dönemin Milli Eğitim Bakanı Vasıf Çınar önlemiştir. Ancak Saraçoğlu bir sonraki dönem Milli Eğitim Bakanı olduğunda bu konuda farklı düşüncelerin olduğunu belirterek yorum yapmaktan kaçınmıştır ${ }^{19}$. Ancak SSCB'deki Türk Devletlerinin 1926 'da Arap harfleri yerine Latin alfabesini kabul etmeleri Türkiye'deki

11 Muhammet Erat, “Osmanlıda Alfabe Tartş̧maları", Türkler, Cilt. 15, Semih Ofset, Ankara, 2002, s. 155.

12 M. Şakir Ülkütaşır, Atatürk ve Harf Devrimi, Türk Dil Kurumu Yayınları, Ankara, 1991, s. 33.

13 Sinan Ateş vd., a.g.e., s. 26.

14 M. Şakir Ülkütaşır, Atatürk ve Harf Devrimi, s. 26. Birinci Dünya Savaşı sırasında Encümen-i Illmiyece kabul olunan harf şekillerine göre düzenlenen ve Islah-ı Huruf Cemiyeti tarafından basılan ve Osmanlı Müdafa-i Milliye Cemiyetine hazırlanılan kitapçık için bkz. Yeni Harflerle Elifba Alfabe, Matbaa-i Hayriye ve Şürekâsı, İstanbul, 1333.

15 Orhan Avcı, Irakta Türk Ordusu, Vadi Yayınları, Ankara, 2004, s. 113.

16 İbrahim Bozkurt, Birgül Bozkurt, "Yeni Alfabenin Kabulü Sonrası Mersin'de Açılan Millet Mektepleri ve Çalışmaları”, Çağdaş Türkiye Tarihi Araştırmaları Dergisi, Cilt: 8, Sayı: 18, 2009, s. 119.

17 Şevket Süreyya Aydemir, Tek Adam, Cilt: III, Remzi Kitabevi, İstanbul, 1999, s. 300.

18 M. Şakir Ülkütaşır, a.g.e., s. 42-43.

19 Agâh Sırrı Levent, a.g.m., s. 27; Şükrü Saraçoğlu'nun TBMM'de Arap harflerinin terki hususunda yaptı̆̆ı konuşma için bkz. TBMM Zabıt Ceridesi, Cilt: 6, Dönem: 2, Birleşim: 111, 25 Şubat 1340, s. 330-336. 
alfabe tartışmalarını da hızlandırmıştır ${ }^{20}$. Bu bağlamda Akşam gazetesinin 28 Mart 1926 tarihinde başlattığı "Latin harflerini kabul etmeli mi, etmemeli mi?" tartışmasında ${ }^{21}$ Arap alfabesi yerine Latin harflerinin kabulünü isteyenler arasında Refet Avni, Abdullah Cevdet ve Mustafa Hamit bulunuyordu. Latin harflerine geçilmesini istemeyenler arasında ise Ali Canib, Ali Ekrem, Muallim Cevdet, İbrahim Alâeddin, Necib Asım, Avram Galanti, Hüseyin Suad, Halil Nimetullah, Veled Çelebi, İbrahim Necmi, Halit Ziya ve Macar Profesör Gömbös Zoltán bulunuyordu. 1926'da yaşanan gelişmelerden sonra harf inkılâbının olacağına kesin gözüyle bakanların artmasına rağmen İzmir Suikastı'nın yaşanması bu durumu geciktirmiştir. Ayrıca 1927'nin de Nutuk yılı olması nedeniyle harf inkılâbının bu yıl içinde yapılması uygun görülmemiştir. Çünkü Mustafa Kemal'e göre Nutuk eski harflerle basııması halinde daha çok okuyucuya ulaşacaktı ${ }^{22}$. Bununla birlikte Mustafa Kemal çevresindeki herkesten farklı olarak yeni alfabenin Türkiye'yi şarklı görüntüsünden kurtaracağı, Türkçeyi istila eden Arapça ve Farsça kelimelerden arındırılabileceğ $\mathrm{i}^{23}$ böylelikle Türk çocuklarının daha kolay okuma yazma öğrenebileceğini de düşünmekteydi ${ }^{24}$.

Cumhuriyetin ilanından sonra hükümet Türk eğitim sistemini geliştirmek için çeşitli uzmanlardan görüş istemiştir. Bunun üzerine 1924'te Türkiye'ye gelen Amerikalı Profesör John Dewey'in hazırladığı rapora göre Türk eğitim sisteminin uzun sürecek bir yenileşmeye intiyaç duyduğu da belirtilmiştir ${ }^{25}$. Ayrıca Dewey'in önerileri ışı̆̆ında yetişkinler eğitimi temel alınarak bir halk eğitiminin yürütülmesi öngörülmüştür. Bu bağlamda Maarif Vekâleti'nin Halk Terbiyesi Şubesi tarafından 1927 yılında Halk Dershaneleri ve Konferansları Talimatnamesi hazırlanmıştır. Ardından bu talimatnameye göre iki gruptan oluşan Halk Dershaneleri açılmıştır' ${ }^{26}$. 22 Mart 1926'da TBMM'de kabul edilen 789 numaralı "Maarif Teşkilatına Dair Kanun"un birinci maddesine göre "Türk dili ve buna müteallik bilcümle ilmi meseleler ile iştigal etmek üzere Maarif Vekâletinde bir Dil Heyeti" kurulmuştur27. 24 Mayıs 1928'de Latin kökenli rakamların alınması kararı harf devrimini de hızlandıran bir gelişme olmuştur ${ }^{28}$. Ardından Milli Eğitim Bakanlığının önerileriyle Latin harflerinin uygulanmasını inceleyecek bir kurul oluşturulması 23 Mayıs 1928 'de Bakanlar Kurulunca kabul edilir29. Harf İnkılâbı hakkında bu düşünceler devam ederken Mayıs 1928'de Dil Encümeni kurulmuştur ${ }^{30}$. Burada tartışılan ilk konu hangi alfabenin alınacağıdır. Komisyondaki bazı kişiler Arapçanın seslerini de kapsayan bir alfabeden yana olurken "milliciler" denen gruba göre de alfabe değişikliğinin yapılmasının temel amacı Türkçeyi Arapça ve Farsçanın etkisinden kurtarmaktır. Dolayısıyla millicilerin görüşü komisyonda baskın gelmiştir ${ }^{31}$. Komisyondaki ikinci tartışma konusu da harflerin öğretim süreleridir. Tartışmada çıkan sonuca göre yeni harflerin öğretimi ya 5 yıl ya da 10

20 Bernard Lewis, Modern Türkiye'nin Doğuşu, Türk Tarih Kurumu Yayınevi, Ankara, 1993, s. 276; Erik Jan Zürcher, Modernleşen Türkiye'nin Tarihi, İletişim Yayınları, İstanbul, 2002, s. 274.

21 “Latin harflerini kabul etmeli mi, etmemeli mi?”, Akşam, Yıl: 8, No: 2680, 28 Mart 1926, s. 1.

22 Sinan Ateş vd., a.g.e, s. 28-29.

23 Fuad Köprülü, "Alfabe İnkılâbı", Belgelerle Türk Tarihi Dergisi, Sayı: 9-10, Kasım- Aralık 1985, s. 31.

24 Muzaffer Uyguner, "Harf İnkılâbı Konusunda", Milli Kültür, Sayı: 63, Aralık, 1988, s. 108.

25 Zafer Tangülü, Oğuzhan Karadeniz ve Sinan Ateş, “Cumhuriyet Dönemi Eğitim Sistemimizde Yabancı Uzman Raporları (1924- 1960), Turkish Studies- International Periodical For The Languages, Literature And History of Turkish or Turkic, Volume 9\5, Ankara, Spring 2014, s. 1898.

26 Fahri Kılıç, "Yeni Türk Alfabesinin Yaygın Eğitim Yoluyla Öğretilmesi”, Ankara Üniversitesi Türk Inkılâp Tarihi Enstitüsü Atatürk Yolu Dergisi, Sayı: 61, Güz 2017, s. 209.

27 Resmi Gazete, No: 338, Yıl: 4, 3 Nisan 1926, s. 1234-1237.

28 Resmi Gazete,No: 900, 28 Mayıs 1928, s. 5221-5222.

29 BCA, 30.18.1.1, 29.32.20, 23 Mayıs 1928.

30 Ankara Doğu Araştırma Merkezi Eğitim Araştırma Grubu, “Dil Encümeni Çalışmaları ve Latin Alfabesi Komisyonunun Modificatıons'u”, Belgelerle Türk Tarihi Dergisi, Sayı: 9-10, Kasım-Aralık 1985, s. 63.

31 Falih Rıfkı Atay, a.g.e., s. 439. 
yılda öğretilebilecektir. Ancak Mustafa Kemal Paşa her iki süreyi de kabul etmemiştir. Bu işin ya üç ayda yapılacağını ya da hiç olmayacağını söylemiştir. Çünkü eski yazı yürürlükte kaldıkça kimsenin yeni yazıyı öğrenmesi mümkün değildi ${ }^{32}$.

Bir aylık çalışmanın ardından encümen adına İbrahim Grandi'nin yazdığı "Elifba Raporu" ve Cevdet Emre'nin yazdığı "Gramer Raporu" ortaya çıkmıştır. Sekiz ana başlı̆̆ı olan Elifba Raporu; Türk dilindeki seslerin miktarı ve keyfiyetleri, Latin harflerinin satvî kıymetleri, Avrupa da kullanılan Latin asıllı harfler, bu alfabelerdeki harflerin şekilleri ve satvî kıymetleri, Türkçeye mahsus Latin harflerinin seçilmesi ve bu hususta tatbik olunan esaslar, muhtelif alfabelerdeki çift harfler işaretli harfler, Latin alfabesine eklenmiş harfler, Türk alfabesini teşkil eden harflerin çeşitli dillerdeki karşılıkları ve tespit edilen yeni alfabenin vasıfları konularını içermektedir. Gramer Raporu'nda ise; yabancı kelimelerde kullanılmak üzere kesme (') ve ayırma (-) işaretlerine yer verilmiştir ${ }^{33}$. Bu çalışmaların ardından yeni harflerin kabulünün yasal zemine oturtulmaya başlanması gerekmiştir. Bunun için 24 Mayıs 1928 tarihinde 1288 sayılı "Beynelmilel Erkamın Kabulü Kanunu" kabul edilmiştir ${ }^{34}$. Ardından 28 Haziran 1928'de Millet Mektepleri hakkında İcra Vekilleri Heyeti kararı yayımlanmıştır ${ }^{35}$.

1928 Ağustos'undan itibaren gazetelerin büyük bir kısmı, sayfalarının bir kısmını yeni harflerle yazılan sütunlara yer vererek, halkı yeni harflere alıştırmaya çalışmışlardır ${ }^{36}$. Yapılan bu çalışmalardan sonra alfabe değişikliği daha resmileşmeden halka sunulması gerektiğini düşünen Mustafa Kemal, 9-10 Ağustos 1928 akşamı Sarayburnu'ndaki bir halk toplantısında yeni Türk Harflerini tanıtmayı uygun bulmuştur. Bu toplantıda bir defter bulunmasını isteyen Mustafa Kemal bu deftere tarihe "Sarayburnu Nutku" olarak geçen söylevi kayda geçmiştir. Daha sonra müziği susturup yazdığı nutku okutmak isteyince toplantıda bulunan hiç kimse okuyamamıştır. Ardından Sarayburnu Nutkunu yeni harflerden haberdar olan Falih Rıfkı Atay okumuştur ${ }^{37}$. Mustafa Kemal Paşa konuşmasında bunun yeni Türk harfleriyle yazıldığını söylemiştir. Bu harflerle zengin ve ahenkli dilimizin kendini göstereceğini belirtmiştir. Ayrıca yeni Türk harfleriyle Türklerin hislerinin bir noktada birleşeceğine olan inancı tam olmalı ve bugüne kadar yapılan işlerin de son olmadığını ifade etmiştir. Paşa, bir ülkenin \%20'si okuryazar, \%80'i okuma yazma bilmiyorsa bundan utanılması gerektiğini ve artık yeni Türk harflerinin öğrenilmesi gerektiğini söylemiştir. Paşa, nutkunu bu yeni Türk harflerini öğrenme ve öğretmenin her Türk vatandaşının görevi olduğunu belirterek bitirmiştir ${ }^{38}$.

Yeni Türk harflerinin tanıtılmasından sonra Dolmabahçe'de bir kurultay toplanmasına karar verilmiştir. Bu kurultayda hem milletvekillerinin yeni alfabeye Isındırılması sağlanacak hem de yazı dilinin ne olacağına karar verilecektir ${ }^{39}$. Dil Kurultay'ı 25 Ağustos 1928 'de saat $10^{\prime}$ da Dolmabahçe Sarayı'nda toplanmıştır ${ }^{40}$. Kurultayda milletvekillerine "Yeni Türk Alfabesi" kitabı dağıtılmıştır. Dil Encümeni üyesi Necmi Dilmen uzun bir ders

32 Lord Kinross, Atatürk: Bir Milletin Yeniden Doğuşu, Çev. Necdet Sander, Altın Kitaplar, İstanbul, 1994, s. 511. 33 Bilal N.Şimşir, a.g.e., s. 92-94.

34 Mahmut Goloğlu, Devrimler ve Tepkileri, Türkiye İş Bankası Kültür Yayınları, İstanbul 2006, s. 276. 1288 sayılı Beynelmilel Erkamın Kabulü Kanunu için bkz. Resmi Gazete, No: 900, 28 Mayıs 1928, s. 5214-5215.

35 Aydın Taneri, “Atatürk ve Harf İnkılâbı”, Milli Kültür, Sayı:63, Aralık 1988, s. 52.

36 Bu konuda 1928 Ağustos tarihli Cumhuriyet, Milliyet ve İkdam gazetelerine bakılabilir.

37 Falih Rıfkı Atay, a.g.e., s. 441-442.

38 Atatürk'ün Söylev ve Demeçleri, Türk İnkılâp Tarihi Enstitüsü Yayınları, Ankara 2006, s. 272-274; Falih Rıfkı Atay, a.g.e., s. 442.

39 Bilal N. Şimşir, a.g.e., s. 176-178.

40 Şimşir, a.g.e., s. 175. 
vererek milletvekillerini sınava tabi tutmuştur ${ }^{41}$. Bu hazırlıklar sonucunda harf inkılâbını kanuni bir zemine oturtmak gerekmiştir. Bu da TBMM'nin ikinci toplantı yılı başı olan 1 Kasım 1928'de Cumhurbaşkanı Gazi Mustafa Kemal Paşa şu konuşmayı yapmıştır: “Büyük Millet Meclisinin kararıla Türk harflerinin katiyet ve kanuniyet kazanması bu memleketin yükselmesinde başlı başına bir geçit olacaktır... Efendiler, Türk harflerinin kabulüyle bu memleketi bütün vatanını seven yetişkin evlatlarına mühim bir vazife tevcih ediliyor. Bu vazife, kâmilen okuyup yazma için gösterdiği şevk ve aşka bilfiil hizmet ve yardım etmektedir. Hepimiz hususî ve umumi hayatımızda rast geldiğimiz okuma yazma bilmeyen erkek, kadın her vatandaşımıza öğretmek için tehalük göstermeliyiz... Hiçbir muzafferiyetin hatalarıla kıyas kabul etmeyen bir muvaffakiyetin heyecanı içindeyiz. Vatandaşlarımızı cehaletten kurtaracak bir sade muallimliğin vicdanî hazzı mevcudiyetimizi işbâ etmiştir"42. Bu konuşmadan sonra da mecliste Latin Harfleri'nin kabulü için görüşmeler yapılmıştır. Ardından ikinci oturumda başkan tasarıyı oylamaya sunarak 1353 sayılı Latin harfleri kanunu yasallaşması sağlanmıştı ${ }^{43}$. TBMM'de harf inkılâbı dolayısıyla Gazi Mustafa Kemal Paşa'ya Türk milletinin şükranlarını ifadesiyle üzerinde yeni harfler bulunan altın bir levha hediye etmiştir ${ }^{44}$.

\section{A- Millet Mektepleri}

Millet Mektepleri yeni alfabenin tüm yurtta öğretilerek, okuryazarlığın arttırılması seferberliğinin önemli bir basamağıdır. Ayrıca Cumhuriyetin yurttaşlık gereği olarak cehaletin ortadan kaldırılmasında da önemli bir görev üstlenmiştir. Millet Mektepleri açılmadan önce Maarif Bakanı İsmail Safa (Özler) döneminde Illköğretim Genel Müdürlüğüne bağlı bir Halk Eğitim Bürosu kurularak halk eğitimi çalışmalarına başlanmıştır. İlköğretim Genel Müdürlüğü, eğitim ve öğretimin birleştirilmesinden sonraki yıllarda çalışmalarını arttırarak 1927-1928 yılları arasında 3.304 adet halk dershanesi açarak, 64.302 kişinin okuma yazma öğrenmesini sağlamıştır ${ }^{45}$. Ancak bu girişim Arap harfleriyle yaygın eğitim çalışmasının başarıya ulaşmayacağını göstermiştir. Bu nedenle Maarif Vekâleti tarafından 1928 Temmuz'unda yeni bir halk mektebi talimatnamesi hazırlanmış, Harf İnkılâbının gerçekleşmesinden sonra da yeni Türk harflerini yurt genelinde halka en kısa sürede en doğru şekilde öğretmek amacıyla sözü edilen dershaneler "Millet Mektepleri" adı altında yeniden düzenlenmiştir. Ardından Türk diline ve yazım kurallarına uygun olduğu kadar, öğrenilmesi de kolay olduğu bilinen ve uluslararası bir alfabe konumunda olduğundan Latin kökenli yeni harfler 1 Kasım 1928 tarihinde kabul edilmiştir ${ }^{46}$.

Millet Mekteplerinin mimarı olan Mustafa Necati tüm yurtta okuma ve yazma seferberliğini başlatmanın gurur ve mutluluğunu "Muallim Arkadaş" başlığıyla yazdığı mektubunda öğretmenlerle paylaşır: "Özellikle bu yıl yeni Türk harflerini genelleştirme gibi onurlu bir ödevin daha vardır. Bütün yurt yavrularını biran önce yeni harflerle

41 Şimşir, a.g.e., s. 180. 1928 yılında yapılan harf devrimi vesilesiyle eski ve yeni harfleri değerlendiren bir çalışmada eski harflerin yetersizliği ve eksikliğinden bahsedilmektedir. Bu konuda geniş bilgi için bkz. Harflerin Değişmesi Münasebetiyle Eski ve Yeni Harfler, Ahmed İhsan Matbaası, İstanbul 1928.

42 Muharrem Ergin, Orhun Abideleri, Boğaziçi Yayınları, İstanbul, 1995, s. 99.

43 Mahmut Goloğlu, a.g.e., s. 258. 1353 sayılı Latin harfleri kanunu için bkz. Resmi Gazete, No: 1030, 3 Teşrinisani 1928 , s. 6001-6003.

44 Lord Kinross, a.g.e., s. 514.

45 Cevat Geray, Halk Eğitimine Giriş, Ankara Üniversitesi Eğitim Fakültesi Yayınları, Ayyıldız Matbaası, Ankara 1970, s. 102.

46 Mustafa Albayrak, “Millet Mekteplerinin Yapısı ve Çalışmaları (1928-1935), Atatürk Araştırma Merkezi Dergisi, Cilt: 10, Sayı: 29, Temmuz 1994, s. 472; Türk Harflerinin kabul ve tatbiki hakkında TBMM görüşmeleri için bkz. TBMM Zabıt Ceridesi, Cilt: 5, 1 Teşrinisani 1928, s. 9-11; Mustafa Ergün, Atatürk Devri Türk Eğitimi, Ocak Yayınları, Ankara 1997, s. 126. 
okutarak Türkiye'de okuma yazma bilmeyen bir tek kişi bırakmayacak ölçüde geniş bir azimle çalışmak zorunluluğundasın. Bunun için yeni Türk harflerini çabuk öğren ve hemen herkese öğretmeye başla. Bu ereğe varmak için kürsü, okul gerekmez. Her yerde gördügünü kadın, erkek, yoksul, zengin, çiftçi, tüccar, köylü ve kentli ayırmayarak hemen ögrreteceksin. Ulusumuza yeni bir yükselme alanı yaratacak olan bu büyük utkuyu kısa bir zamanda kazanacağına kanmış olarak görevlerinde başarı diler ve işe başlama haberini beklerim". "Türkiye'de okuma yazma bilmeyen bir tek kişi bırakmayacak" kadar büyük bir azimle çalışmaktan söz eden Millet Mekteplerinin mimarı Mustafa Necati, ne yazık ki Millet Mekteplerinin açıldığı gün 1 Ocak 1929'da hayatını kaybetmiştir ${ }^{47}$.

Millet Mektepleri'nin açılışı, 11 Kasım 1928 tarihli Bakanlar Kurulu Kararnamesi ile kabul edilmiş ${ }^{48}$ ve bu kararnamenin 24 Kasım 1928 tarihinde Resmi Gazetede yayınlanmasıyla Maarif Vekâletince hazırlanan ilk "Millet Mektepleri Teşkilatı Talimatnamesi" yürürlüğe girmiştir ${ }^{49}$. Elli iki maddeden oluşan talimatnamenin birinci maddesinde Millet Mekteplerinin amacı şöyle belirtilmiştir: "Türkiye Büyük Millet Meclisi tarafından Türk dilinin ferdi ve umumi, hususi ve resmi bilcümle muharreratta Türk harfleri ile tesbiti kanunen kabul edilmiş olmasından bu kanuna müsteniden tatbikatta vuzuh ve veçhe iraesi için yeni Türk harflerinin kısa bir zamanda ve kolay surette her ferde okuyup yazabilmek imkânını bahşeden mahiyetinden Türk Milletini azami surette istifade ettirmek ve büyük halk kütlelerini süratle okuryazar bir hale getirmek maksadıyla Millet Mektebi teşkilatı yapılmışı ı́o". Bu talimatname ile hiç okuma-yazma bilmeyen vatandaşlara yeni Türk harfleri ile okuma yazmayı öğrenmeleri için dört ay süreli $A$ dershanesi ve okuma-yazma bilenlere iki ay süreli B dershaneleri açılmıştır. Ayrıca talimatnamede dershanelere devam etmek zorunda olan vatandaşların yaş aralığının 16 ile 45 olduğu, ${ }^{51}$ Halk Fırkası ve Türk Ocağı'nın da Millet Mektepleriyle koordineli çalışacağı da eklenmiştir ${ }^{52}$. Aynı zamanda valilerin yılda iki defa Millet Mekteplerinde yapılan işleri Milli Eğitim Bakanlığına rapor etmekle de yükümlü tutulmuştur ${ }^{53}$.Talimatnamede Millet Mektebi (A) ve (B) dershanelerine devam edenlerin sınavla mezun edileceği açıklanmıştır. Mezuniyet vesikalarının da mart ayı içinde verileceği belirtilmiştir ${ }^{54}$. Halkın Millet Mekteplerindeki başarılarını arttırmak için en başarılı ve öğrenme kabiliyeti olan bir kadın ve erkeğe imtihanlar sonunda mezuniyet belgesi yanında "Teşkilat-ı Esasiye" kitapçığı da verilmiştir ${ }^{55}$. Bu kitapçıkta ilk önce başarılı olan öğrencinin adının yazılı olduğu sayfa, Gazi'nin imzalı resmi, gençliğe hitabe ve anayasa bulunuyordu ${ }^{56}$. Talimatnamede ayrıca Millet Mektepleri idare heyetlerinin yerel gazeteler, tellallar aracılı̆̆ıyla duyuru ile halkı teşvik etmeleri istenmiştir ${ }^{57}$. Ayrıca bu kurslara gitmeyenlere verilecek cezalar da talimatnamede açıklanmıştır ${ }^{58}$. Talimatnamede Millet Mekteplerinin (B) dershanesinde okutulacak olan "Kıraat ve Tahrir, Hesap ve Ölçüler, Yurt Bilgisi ve Sağlık Bilgisi" dersleri hakkında da bilgi verilmiştir ${ }^{59}$.

47 Şimşir, a.g.e, s. 208.

48 BCA, 30.18.1.2, 1.1.13, 11.11.1928.

49 Resmi Gazete, Sayı: 1048, 24 Teşrinisani 1928, s. 6102-6107.

50 Resmi Gazete, Sayı: 1048, 24 Teşrinisani 1928, s. 6102-6107.

51 BCA, 490,1, 1.3.12, 22.09.1929, Ek 10- 11.

52 BCA, 490,1, 1.3.12, 22.09.1929, Ek 12- 13.

53 BCA, 490,1, 1.3.12, 22.09.1929, Ek 13.

54 BCA, 490,1, 1.3.12, 22.09.1929, Ek 16.

55 Mücteba İlgürel, "Millet Mektepleri”, Doğumunun 100. Yılında Atatürk'e Armağan (Ayrı Basım), Edebiyat Fakültesi Matbaası, İstanbul, 1981, s. 33.

56 ilgürel, a.g.m., s. 34.

57 BCA, 490,1, 1.3.12, 22.09.1929, Ek 18.

58 BCA, 490,1, 1.3.12, 22.09.1929, Ek 19.

59 BCA, 490,1, 1.3.12, 22.09.1929, Ek 27. 
Millet Mektepleri talimatnamelerde üç farklı şekilde belirtilmişse de sonradan iki tür daha eklenmiştir:

Sabit Millet Mektepleri: Bu tür Millet Mektepleri genellikle okul, cami, kahvehane, Halk Fırkası veya Türk Ocağı binaları gibi yerlerde halkın eğitim-öğretim faaliyetleri yapılmıştır. Buralardaki dershaneler Kasım'da eğitime başlayıp Şubat sonuna kadar planlanmıştır ${ }^{60}$. Bu bağlamda Sinop'ta da kent merkezinde bulunan bu tür binalarda Millet Mektepleri dershaneleri açılmıştır.

Seyyar Millet Mektepleri: Bu dershaneler okul olmayan yerlerde açılarak okumayazma eğitimi de seyyar öğretmenler tarafından yapılmıştır. Bu dershanelerde de eğitimöğretim Kasım'da eğitime başlayıp Şubat sonuna kadar faaliyetlerini sürdürmüştür ${ }^{61}$. Sinop'ta da özellikle köy mektebi bulunmayan yerlerde Seyyar Millet Mektepleri açılmıştır.

Özel Millet Mektepleri: Bu dershaneler devlet kuruluşları, belediyeler ve özel teşebbüslerin personellerini okur-yazar yapmak için açılan okullardır. Sinop'ta da 19281929, 1930-1931 ve 1933-1934 yılları arasında özel millet mekteplerinin açıldığını görmekteyiz ${ }^{62}$.

Köy Yatı Dershanesi: Okulların olmadığı köylerde çocuklara okuma yazma öğretmek amacıyla mali duruma göre her vilayet veya kaza merkezinde açılması planlanmıştır. Köy Yatı Dershaneleri mektebi olmayan köylerdeki çocukların köylerden alınarak okumayazmayı öğrenmesi sağlandıktan sonra tekrar köylere gönderilmesini amaçlamıştır.

Halk Okuma Odası: Okuma-yazma öğrenen vatandaşların okumalarını geliştirmek, sosyal ve ekonomik hayatlarıla ilgili bilgiler verilmesi amacıyla kurulmuştur ${ }^{63}$.

\section{B- Sinop'ta Millet Mektepleri}

1926 yılı Sinop'taki eğitim kurumlarının durumuna baktığımızda karşımıza şöyle bir tablo çıkmaktadır. Sinop merkezinde bir ortaokul ve bir yatılı ilkokul bulunmakla beraber gündüz eğitim yapan kızlara mahsus bir ilkokul da bulunuyordu. Ayrıca Sinop merkezine bağlı 16 köy okulu, Ayancık kazasında da bir erkek ve bir kız okulu ile 9 köy okulu; Gerze kazasında bir erkek ve kız ilkokulu ile 8 köy ilkokulu mevcuttu. Bu okullara giden öğrenci sayısının ise 2314 olduğu ve bu okullarda eski tarzda iptidai koşullarda eğitim verildiği görülür ${ }^{64}$.

Türkiye geneli okuryazarlık durumuna baktığımızda 28 Ekim 1927 tarihli genel nüfus sayımı verileri Türkiye genelinde 1.111 .000 kişinin Arap harfleriyle okuma bildiğini göstermektedir. Ayrıca Maarif 1928-35 Millet Mektepleri Faaliyeti İstatistiği ve Maarif 1928-33 Millet Mektepleri Faaliyeti İstatistiği verilerinin ise sadece Millet Mekteplerinden mezun olanları gösterdiğini dikkate aldığımızda ise 1928-1933 yılları arasındaki bu beş yıllık sürede yeni harfleri öğrenenlerin sayısı 1.247.197 dir. Ancak Türkiye genelinde bu beş yıllık sürede okuryazar sayısı bundan üç dört kat daha fazladır. Çünkü bu beş yıllık süre içerisinde Millet Mektepleri dışında birçok devlet ve özel kurum, belediye, 18000

60 Resmi Gazete, No: 1048, 24 Teşrinisani 1928, s. 6102-6107; Resmi Gazete, No: 1321, 16 Teşrinievvel 1929, s. 8395-8402; Millet Mektepleri Talimatnamesi, Köy Hocası Matbaası, Ankara, 1929.

61 Resmi Gazete, No: 1048, 24 Teşrinisani 1928, s. 6102-6107; Resmi Gazete, No: 1321, 16 Teşrinievvel 1929, s. 8395-8402; Millet Mektepleri Talimatnamesi, Köy Hocası Matbaası, Ankara, 1929.

62 Maarif Millet Mektepleri Faaliyet istatistiği 1928-1934, s. 41.

63 Resmi Gazete, No: 1048, 24 Teşrinisani 1928, s. 6102-6107; Resmi Gazete, Sayı: 1321, 16 Teşrinievvel 1929,

s. 8395-8402; Millet Mektepleri Talimatnamesi, Köy Hocası Matbaası, Ankara, 1929.

64 Türkiye Cumhuriyeti Devlet Salnamesi (1925-1926), Matbaa-i Amire, İstanbul, 1926, s. 649. 
civarında öğretmen, yarım milyondan fazla öğrenci, asker, polis, banka ve şirketler ile kendi çabalarıyla öğrenen birçok kişi bu sayılara dâhil değildir. Dolayısıyla bunlar da dikkate alındığında Latin harfleriyle okuma yazma öğrenenlerin sayısının üç milyonu geçtiğini söyleyebiliriz ${ }^{65}$.

Sinop özeline baktığımızda ise 28 Ekim 1927 tarihli genel nüfus sayımında şehirde Arap harfleriyle okur-yazarlık durumunun düşük olduğu görülmektedir. Buna göre Sinop 169.965 nüfusuyla ${ }^{66}$ diğer Karadeniz illeri içinde Kastamonu, Trabzon, Zonguldak, Samsun, Bolu, Ordu, Rize, Giresun'dan sonra geldiği anlaşılmaktadır. Buradaki rakamlara göre Sinop'ta 162.626 kişi okuma yazma bilmemekte olup sadece 7339 kişi okuma yazma bildiği anlaşılmaktadır67 1927 yılı genel nüfus sayımı verilerinden de anlaşıldığı üzere şehirde okuma-yazma bilen sayısının düşüklüğü görülmektedir. Bu nedenle harf inkılâbının Sinop şehri özelinde de gerekliliği anlaşılmaktadır.

Harf İnkılâbı'nın sadece okullarda sınırlı kalmaması için okul yaşını çoktan geçmiş vatandaşlarında yeni harfleri öğrenebilmeleri için her yıl 1 Ocak 1929'da Millet Mekteplerinin açılması kararlaştırılmıştır ${ }^{68}$. Bu mekteplerde yapılacak işlerde ikinci bir talimatnamede belirtilerek 22 Eylül 1929'da yürürlüğe girmiştir ${ }^{69}$. Sinop’ta Harf İnkılâbı çalışmaları yurdun diğer köşelerinde olduğu gibi daha resmileşmeden Mustafa Kemal'in, Sinop gezisi ile başlamıştır. 15 Eylül 1928' de Mustafa Kemal Paşa, Harf İnkılâbını tanıtmak için Sinop'a gitmiştir. Sinop Hükümet Konağında biraz dinlenen Mustafa Kemal Paşa yatı mektebine giderek bahçeye bir yazı tahtası getirtilmesini istemiştir. Bahçede toplanmış olan halk da yarım ay şeklinde Mustafa Kemal Paşa'nın yeni harfleri öğretmesini izlemiştir ${ }^{70}$. Mustafa Kemal burada derse sesli harfleri tanıtmakla başlamış ve bir okuma parçası okuduktan sonra herkese okutarak yazdırmıştır. İlk olarak Sinop'taki kültür ve ortaokul direktörleri ile başlamış ve sınavlar da halkın büyük bir çoğunluğu da başarılı olmuştur. Sınavlara devam ederken 50 yaşlarında olan ve Sinop'ta arabacı Bekir Ağa olarak bilinen bir adamı tahtaya çă̆ırmıştır. Mustafa Kemal Paşa'nın burada olma nedenini sorması üzerine okuma yazması olmayan Bekir Ağa bunu öğrenmek için geldiğini söylemiştir. Mustafa Kemal Paşa tahtaya bir $A$ harfi yazarak birkaç kelime örneği ile bu harfi Bekir Ağa'ya öğretmiştir. Paşa daha sonra o, ö, u, ü sesli harflerini de Bekir Ağa'ya öğretmiştir. Ardından Mustafa Kemal Paşa, Bekir Ağa'ya bir de $T$ harfini öğretmiştir. Bu harfleri öğrenen Bekir Ağa AT ve OT kelimelerini yanlışsız yazmıştır. Bu başarısından dolayı Bekir Ağa, Mustafa Kemal Paşa'ya teşekkür etmiştir. Birkaç saniye sonra Paşa'yı öven bir nutuk söylemeye başlamıştır. Ancak Mustafa Kemal Paşa tarafından susturulmuş eline bir kıraat kitabı verilerek çalışmaya devam etmesi söylenmiştir. Bekir Ağa bundan sonra her yazıdaki $A$ ve $O$ harfleri sesli okumuştur. Ayrıca $A T$ ve $O T$ kelimelerini yazıp herkese göstermeye başlamıştır. 50 yaşından sonrada kendisini okuttuğu için Gazi'yi daima şükranla anmıştır. Aynı günün akşamı Sinop yalıdaki parkta da harf inkılâbı, Türk dili ve tarihine ait meseleler konuşulmuştur. Saat 1'e doğru Mustafa Kemal Paşa parktakilerden

65 Maarif 1928-33 Millet Mektepleri Faaliyeti istatistiği, Başvekalet İstatistik Umum Müdürlüğü, Devlet Matbaası, İstanbul, 1934, s. 1.

6628 Teşrinievvel 1927 Umumî Nüfus Tahriri: Usuller Kanun ve Talimatnameler Neticelerin Tahlili, III. Fasikül, Başvekâlet Müdevvenat Matbaası, Ankara, 1929, s. 141-142.

6728 Teşrinievvel 1927 Umumî Nüfus Tahriri: Usuller Kanun ve Talimatnameler Neticelerin Tahlili, III. Fasikül, Başvekâlet Müdevvenat Matbaası, Ankara, 1929, s. 141-142.

68 BCA, 490.1, 1.2.13, 25.12.1928.

69 Başbakanlık Cumhuriyet Arşivi (BCA), 490,1, 1.3.12, 22.09.1929, Ek 9.

70 M. Şakir Ülkütaşır, "Harf İnkılâbımıza Aid Bir Hatıra: Büyük Öğretmen Atatürk Halk İçin Başladıkları Alfabe Derslerinin Illkini Sinobda Vermişlerdi”, Bartın, Yıl: 15, Sayı: 666, 27 Teşrinievvel 1938, s. 2. 
izin istemiştir. O anda "Nasıl göndeririz? Daha doyamadık ki" nidası yükselmiştir. Bunu duyan Paşa gülerek parktan ayrılmıştır ${ }^{71}$.

1 Kasım 1928'de kabul edilen ve 3 Kasım 1928'de yürürlüğe giren, "Yeni Türk Alfabesi"nin kabulü sonrası tüm ülkede olduğu üzere Sinop'ta da okuma-yazma seferberliği başlatılmıştır. Bunun üzerine Sinop'ta da Millet Mektepleri yeni Türk alfabesiyle okuma-yazma öğretmek amacıyla ilgili kararnamenin yayınlanmasının ardından açılmıştır. Bu dönemde Sinoplulara Millet Mektepleriyle ilgili duyuru yapacak yerel bir gazetenin olmaması nedeniyle duyurular tellallar aracılığıyla yapılmıştır. Harf İnkılâbının resmileşmesinden sonra okul yaşı geçmiş vatandaşların hem yeni harfleri öğrenmesi hem de cumhuriyete uygun bir yurttaş olabilmeleri için Sinop'ta da Millet Mektepleri açılmıştır. Sinop Millet Mekteplerinin 1928-1934 yılları arasındaki çalışmalarına baktığımızda Millet Mekteplerinin (A) ve (B) dershanesi olarak hem merkezde hem de köylerinde teşkilatlandığını görmekteyiz.

Tablo 1: Sinop şehir merkezindeki Millet Mekteplerinin dağılımı².

\begin{tabular}{|l|l|l|l|l|}
\hline \multirow{2}{*}{ Yıl Aralı̆̆ı } & \multicolumn{2}{|c|}{ (A) Dershanesi } & \multicolumn{2}{c|}{ (B) Dershanesi } \\
\cline { 2 - 6 } & E & K & E & K \\
\hline $1928-1929$ & 20 & 11 & 9 & 8 \\
\hline $1929-1930$ & 17 & 13 & - & - \\
\hline $1930-1931$ & 19 & 11 & 2 & 1 \\
\hline $1931-1932$ & 5 & 4 & - & - \\
\hline $1932-1933$ & 4 & - & 1 & 1 \\
\hline $1933-1934$ & 4 & 2 & 1 & 1 \\
\hline $1934-1935$ & 1 & 1 & 2 & - \\
\hline Toplam & 70 & 42 & 15 & 11 \\
\hline
\end{tabular}

Yukarıdaki tabloda görüldüğü üzere Sinop Millet Mekteplerinin hem (A) hem de (B) dershanelerinde erkek ve kadınlara mahsus ayrı sınıfların açıldığı görülmektedir. (A) ve (B) dershanelerinde erkeklere mahsus dershanelerin kadınlarınkinden fazla olduğu anlaşılmaktadır. Ayrıca (B) dershanesinin açılma oranı da hem erkek hem de kadında (A) dershanesinden daha az olduğu görülmekle birlikte 1929-1930 ve 1931-1932 yıllarında (B) dershanesinin açılmamış olması da Sinop şehir merkezinde bu dershaneye ilginin de az olduğunun bir başka göstergesidir. Buna karşın Sinop şehir merkezinde 1928-1934 yılları arasında kadın ve erkeklere mahsus olmak üzere toplamda 112 adet Millet Mektebi (A) dershanesi ve 26 adet (B) dershanesi açıldığı gözlenmektedir.

1928-1934 yılları arasında Sinop köylerinde de Millet Mektepleri teşkilatlanarak (A) ve (B) dershaneleri açılmıştır.

71 Ülkütaşır, "Harf İnkılâbımıza Aid Bir Hatıra: Büyük Öğretmen...", s. 2.

72 Maarif 1928-35 Millet Mektepleri Faaliyeti İstatistiği, Başvekalet İstatistik Umum Müdürlüğü, Hüsnütabiat Matbaası, İstanbul, 1935, s. 60. 
Tablo 2: Sinop'un köylerindeki Millet Mekteplerinin dağılımı ${ }^{73}$.

\begin{tabular}{|l|l|l|l|l|}
\hline \multirow{2}{*}{ Yıl Aralığı } & \multicolumn{3}{|c|}{ (A) Dershanesi } & \multicolumn{2}{c|}{ (B) Dershanesi } \\
\cline { 2 - 6 } & E & K & E & K \\
\hline $1928-1929$ & 35 & 2 & 3 & 1 \\
\hline $1929-1930$ & 43 & 1 & - & - \\
\hline $1930-1931$ & 51 & - & - & - \\
\hline $1931-1932$ & 18 & 1 & - & - \\
\hline $1932-1933$ & 16 & - & - & - \\
\hline $1933-1934$ & 55 & - & 1 & - \\
\hline $1934-1935$ & 8 & - & 4 & - \\
\hline Toplam & 226 & 4 & 8 & 1 \\
\hline
\end{tabular}

Yukarıdaki tablodan anlaşıldığı üzere Sinop köylerindeki Millet Mektebi (A) ve (B) dershanelerinde de erkek ve kadınlara mahsus ayrı sınıflar açıldığı gözlenmektedir. (A) dershanesinin köylerdeki faaliyetine baktığımızda erkeklere mahsus dershanelerinin kadınlara mahsus dershanelerden fazla olduğu anlaşılmaktadır. Aynı zamanda Millet Mektebi (B) dershanesine köylerde hem kadınların hem de erkeklerin fazla ilgi göstermediği de görülmektedir. Ayrıca Sinop'un köylerinde açılan Millet Mekteplerinin sayısının şehir merkezinden çok olduğu da göze çarpmaktadır. Bu durum nüfusun köylerde daha yoğun olduğunun da göstergesidir.

Millet Mekteplerinde görev yapan öğretmenlerle ilgili "Maarif Millet Mektepleri Faaliyet istatistiği 1928-1934" başlıklı raporda yer verilmiştir. Buna göre 1928-1934 yılları arasında Sinop şehir merkezindeki (A) ve (B) dershanelerinde birçok kadın ve erkek öğretmenin görev yaptığını görmekteyiz.

Tablo 3: Sinop şehir merkezlerindeki öğretmenlerin dağılımı ${ }^{74}$.

\begin{tabular}{|l|l|l|l|l|}
\hline \multirow{2}{*}{ Yıl Aralığı } & \multicolumn{3}{|c|}{ (A) Dershanesi } & \multicolumn{2}{c|}{ (B) Dershanesi } \\
\cline { 2 - 6 } & E & K & E & K \\
\hline $1928-1929$ & 20 & 11 & 9 & 8 \\
\hline $1929-1930$ & 17 & 13 & - & - \\
\hline $1930-1931$ & 19 & 11 & 2 & 1 \\
\hline $1931-1932$ & 5 & 4 & - & - \\
\hline $1932-1933$ & 4 & - & 2 & - \\
\hline $1933-1934$ & 4 & 2 & - & - \\
\hline $1934-1935^{*}$ & 3 & 1 & - & - \\
\hline Toplam & 72 & 42 & 13 & 9 \\
\hline
\end{tabular}

Yukarıdaki tabloda görüldüğü üzere Sinop'taki Millet Mektepleri hem (A) hem de (B) dershanesinde görev yapan erkek öğretmenlerin kadın öğretmenlerden daha fazla olduğu anlaşılmaktadır. Bu durum erkek katılımcıların daha fazla olmasından kaynaklanmaktadır.

73 Maarif 1928-34 Millet Mektepleri Faaliyet istatistiği, s. 40

74 Maarif 1928-34 Millet Mektepleri Faaliyet istatistiği, s. 40. 
Aynı zamanda Sinop'ta Millet Mektebi (B) dershanesine ilginin az olmasından dolayı burada görev yapan hem erkek hem de kadın öğretmenlerin sayısı (A) dershanesinde görev yapanlardan az olduğu da görülmektedir. Ayrıca 1929-1930, 1931-1932 ve 19331934 yılları arasında da Sinop şehir merkezindeki Millet Mektebi (B) dershanesinde hiçbir öğretmenin de görev almadığı gözlenmektedir.

1928-1934 yılları arasında Sinop köylerinde açılan Millet Mekteplerinde de okumayazma eğitimi yoğun olarak devam etmiştir. Bu bağlamda Sinop köylerindeki Millet Mektepleri (A) ve (B) dershanelerinde de birçok kadın ve erkek öğretmen görev yapmıştır. Ancak erkek ve kadın öğretmenlerin dağııımında büyük fark olduğu da göze çarpmaktadır.

Tablo 4: Sinop köylerindeki Millet Mekteplerinde görev yapan öğretmenlerin dağılımı ${ }^{75}$.

\begin{tabular}{|l|l|l|l|l|}
\hline \multirow{2}{*}{ Yıl Aralığı } & \multicolumn{3}{|c|}{ (A) Dershanesi } & \multicolumn{2}{c|}{ (B) Dershanesi } \\
\cline { 2 - 6 } & E & K & E & K \\
\hline $1928-1929$ & 35 & 2 & 3 & 1 \\
\hline $1929-1930$ & 43 & 1 & - & - \\
\hline $1930-1931$ & 51 & - & - & - \\
\hline $1931-1932$ & 18 & 1 & - & - \\
\hline $1932-1933$ & 16 & - & - & - \\
\hline $1933-1934^{*}$ & 50 & 6 & - & - \\
\hline $1934-1935$ & 16 & 1 & - & - \\
\hline Toplam & 229 & 11 & 3 & 1 \\
\hline
\end{tabular}

Yukarıdaki tablodan anlaşıldığı üzere Sinop köylerindeki Millet Mektepleri (A) dershanesinde görev yapan erkek öğretmenlerin kadın öğretmenlerden çok fazla olduğu gözlemlenmektedir. Aynı durum Sinop köylerindeki (B) dershanesi için de geçerli olmakla birlikte 1929-1930, 1930-1931, 1931-1932, 1932-1933 ve 1933-1934 yıllarında (B) dershanesinde hiçbir öğretmenin görev yapmadığı dikkat çekmektedir. Bu durum köylülerin yoğun çalışma hayatına sahip olmasından kaynaklandığını söylenebilir. Ayrıca köylülerin sadece okuma yazmayı öğrenmekle yetindiğinin de göstergesidir.

1928-1934 yılları arasında Sinop merkezindeki Millet Mektebi (A) ve (B) dershanelerine büyük miktarda kadın ve erkek katılımcının kayıt yaptırdığı görülmektedir.

75 Maarif 1928-35 Millet Mektepleri Faaliyeti İstatistiği başlıklı yayında eğitmenlerin A ve B dershanelerine göre dağılımı verilmediğinden bu öğretmenler tabloda A dershanesi eğitmeni olarak gösterilmiştir. Bkz. Maarif 1928-35 Millet Mektepleri Faaliyeti İstatistiği, Başvekalet İstatistik Umum Müdürlüğü, Hüsnütabiat Matbaası, İstanbul, 1935, s. 60-61. 
Tablo 5: Sinop merkezindeki Millet Mekteplerine kayıt yaptıranların dağılımı ${ }^{76}$.

\begin{tabular}{|l|l|l|l|l|}
\hline \multirow{2}{*}{ Yıl Aralı̆̆ı } & \multicolumn{3}{|c|}{ (A) Dershanesi } & \multicolumn{2}{c|}{ (B) Dershanesi } \\
\cline { 2 - 5 } & E & K & E & K \\
\hline $1928-1929$ & 1.196 & 708 & 124 & 92 \\
\hline $1929-1930$ & 580 & 384 & - & - \\
\hline $1930-1931$ & 511 & 343 & - & - \\
\hline $1931-1932$ & 132 & 192 & - & - \\
\hline $1932-1933$ & 122 & - & 39 & 33 \\
\hline $1933-1934$ & 116 & 26 & 74 & 18 \\
\hline $1934-1935$ & 45 & 23 & 64 & - \\
\hline Toplam & 2702 & 1676 & 301 & 143 \\
\hline
\end{tabular}

Yukarıdaki tabloda görüldüğü üzere Sinop merkezindeki Millet Mektepleri (A) dershanesindeki katılımcı sayısında erkeklerin fazlalığı göze çarpmaktadır. Buna karşın sadece 1931-1932 yılları arasında kadınların sayısının erkeklerden fazla olduğu tespit edilmiştir. Sinop merkezindeki Millet Mektebi (B) dershanesinde ise (A) dershanesine nazaran katılımın az olduğu ve erkek öğrenci sayısının kadınlardan fazla olduğu da anlaşılmaktadır. Ayrıca Sinop merkezindeki Millet Mektebi (B) dershanesine 1929-1930, 1930-1931 ve 1931-1932 yıllarında hiçbir kayıt yaptıranın bulunmaması da halkın bu dershanelere rağbet göstermediğinin göstergesidir.

1928- 1934 yılları arasında Sinop'un köylerindeki Millet Mektebi (A) ve (B) dershanelerine kayıt yaptıran kadın ve erkeklerin sayısı şehir mezkezindekinden daha çok olduğu görülmektedir.

Tablo 6: Sinop köylerindeki Millet Mekteplerine kayıt yaptıranların dağılımı ${ }^{77}$.

\begin{tabular}{|l|l|l|l|l|}
\hline \multirow{2}{*}{ Yıl Aralığı } & \multicolumn{3}{|c|}{ (A) Dershanesi } & \multicolumn{2}{c|}{ (B) Dershanesi } \\
\cline { 2 - 5 } & E & K & E & K \\
\hline $1928-1929$ & 1.350 & 760 & 1.013 & 503 \\
\hline $1929-1930$ & 2.000 & 1.700 & - & - \\
\hline $1930-1931$ & 1.575 & 349 & - & - \\
\hline $1931-1932$ & 618 & 32 & - & - \\
\hline $1932-1933$ & 539 & - & - & - \\
\hline $1933-1934$ & 1.481 & 332 & 30 & - \\
\hline $1934-1935$ & 353 & 101 & 150 & 10 \\
\hline Toplam & 7916 & 3274 & 1193 & 513 \\
\hline
\end{tabular}

Yukarıdaki tabloda görüldüğü üzere Sinop köylerindeki Millet Mektepleri (A) ve (B) dershanelerindeki katılımcı sayısına bakıldığında erkeklerin kadınlardan fazla olduğu

76 Maarif 1928-34 Millet Mektepleri Faaliyet İstatistiği, s. 40.

77 Maarif 1928-34 Millet Mektepleri Faaliyet Istatistiği, s. 40. 
anlaşılmaktadır. Ayrıca 1929-1930 yıllarında Sinop köylerindeki Millet Mektepleri (A) dershanesinde eğitim gören kadınların sayısının bir önceki yıla göre artış gösterdiği de saptanmıştır. Aynı zamanda (B) dershanesine hem erkek hem de kadın sayısı açısından (A) dershanesine oranla daha az olduğu gözlenmektedir.

1928-1934 yılları arasında Sinop merkezindeki Millet Mektepleri (A) ve (B) dershanelerine kayıt olanlardan daha az katılımcının derslere devam ettiği anlaşılmaktadır.

Tablo 7: Sinop şehir merkezindeki katılımcıların devamlılık dağılımı ${ }^{78}$.

\begin{tabular}{|l|l|l|l|l|}
\hline \multirow{2}{*}{ Yıl Aralığı } & \multicolumn{3}{|c|}{ (A) Dershanesi } & \multicolumn{2}{c|}{ (B) Dershanesi } \\
\cline { 2 - 5 } & E & K & E & K \\
\hline $1928-1929$ & 357 & 318 & 84 & 50 \\
\hline $1929-1930$ & 453 & 247 & - & - \\
\hline $1930-1931$ & 390 & 89 & 37 & 1 \\
\hline $1931-1932$ & 116 & 71 & - & - \\
\hline $1932-1933$ & 85 & - & 39 & 33 \\
\hline $1933-1934$ & 30 & 7 & 34 & 15 \\
\hline $1934-1935$ & 18 & 4 & 31 & - \\
\hline Toplam & 1449 & 736 & 225 & 99 \\
\hline
\end{tabular}

Yukarıdaki tablodan anlaşıldığı üzere 1928-1934 yılları arasında Sinop merkezindeki Millet Mektebi (A) ve (B) dershanelerine kayıt yaptıranların çoğunun derslere devam etmediği anlaşılmaktadır. Her iki dershanede de erkeklerin kadınlardan daha fazla devam ettiği de gözlenmektedir. Ayrıca (A) dershanesinin devamlılık oranı (B) dershanesinden daha yüksek olduğu göze çarpmaktadır.

Sinop köylerinde 1928-1934 yılları arasında açılan Millet Mektebi (A) ve (B) dershanelerine kayıt yapanlarında çoğunun derslere devamsızlık yaptığı görülmektedir.

Tablo 8: Sinop köylerindeki katılımcıların devamlılık dağılımı ${ }^{79}$.

\begin{tabular}{|l|l|l|l|l|}
\hline \multirow{2}{*}{ Yıl Aralığı } & \multicolumn{3}{|c|}{ (A) Dershanesi } & \multicolumn{2}{c|}{ (B) Dershanesi } \\
\cline { 2 - 5 } & $E$ & $K$ & $E$ & $K$ \\
\hline $1928-1929$ & 993 & 442 & 929 & 453 \\
\hline $1929-1930$ & 1.073 & 232 & - & - \\
\hline $1930-1931$ & 759 & 149 & - & - \\
\hline $1931-1932$ & 335 & 18 & - & - \\
\hline $1932-1933$ & 288 & - & - & - \\
\hline $1933-1934$ & 594 & 96 & 5 & - \\
\hline $1934-1935$ & 162 & 28 & 47 & 3 \\
\hline Toplam & 4204 & 965 & 981 & 456 \\
\hline
\end{tabular}

78 Maarif 1928-34 Millet Mektepleri Faaliyet istatistiği, s. 41.

79 Maarif 1928-34 Millet Mektepleri Faaliyet Istatistiği, s. 41. 
Yukarıdaki tabloda görüldüğü üzere 1928-1934 yılları arasında Sinop köylerindeki Millet Mektebi (A) ve (B) dershanelerinin devamlılığında erkeklerin kadınlardan fazla olduğu görülmektedir. Ancak (B) dershanesine 1929-1930, 1930-1931, 1931-1932 ve 1932-1933 yılları arasında hiç kimsenin devam etmediği de göze çarpmaktadır.

1928-1934 yılları arasında Sinop şehir merkezinde Millet Mektepleri dışında özel derslerle okuma yazma öğrenenler olduğu görülmektedir.

Tablo 9: Sinop merkezde Millet Mektepleri dışında ders alanların dağılımı ${ }^{80}$.

\begin{tabular}{|l|l|l|l|l|}
\hline \multirow{2}{*}{ Yıl Aralığı } & \multicolumn{3}{|c|}{ (A) Dershanesi } & \multicolumn{2}{c|}{ (B) Dershanesi } \\
\cline { 2 - 5 } & E & K & E & K \\
\hline $1928-1929$ & 460 & 92 & - & - \\
\hline $1929-1930$ & - & - & - & - \\
\hline $1930-1931$ & 2 & 1 & - & - \\
\hline $1931-1932$ & - & - & - & - \\
\hline $1932-1933$ & - & - & - & - \\
\hline $1933-1934$ & 41 & - & 150 & - \\
\hline $1934-1935$ & 3 & - & - & - \\
\hline Toplam & 506 & 93 & 150 & - \\
\hline
\end{tabular}

Yukarıdaki tablodan anlaşıldığı üzere Sinop'ta 1928-1934 yılları arasında Millet Mektebi dışında özel dershanelere de ilginin orta düzeyde olduğu görülür. Özel dershanelerde (A) dershanesinin daha yoğun olduğu ayrıca burada ders alan erkeklerinde kadınlardan fazla olduğu gözlenmiştir. (B) dershanesine özel ders konusunda ise fazla rağbet olmamasına rağmen 1933-1934 yılları arasında sadece 150 erkeğin (B) dershanesinde ders aldığı saptanmıştır. 1928-1933 yılları arasında Sinop köylerinde hiçbir erkek ve kadının (B) dershaneleri için dışarıdan özel ders almadığı da görülmektedir. Ayrıca 1929-1930 ve 1931-1933 yılları arasında özel (A) dershanelerinin de açılmadığı anlaşılmaktadır.

Tablo 10: Sinop köylerinde Millet Mektepleri dışında ders alanların dağılımı ${ }^{81}$.

\begin{tabular}{|l|l|l|l|l|}
\hline \multirow{2}{*}{ Yıl Aralığı } & \multicolumn{3}{|c|}{ (A) Dershanesi } & \multicolumn{2}{c|}{ (B) Dershanesi } \\
\cline { 2 - 6 } & E & K & E & K \\
\hline $1928-1929$ & 40 & 15 & - & - \\
\hline $1929-1930$ & - & - & - & - \\
\hline $1930-1931$ & - & - & - & - \\
\hline $1931-1932$ & - & - & - & - \\
\hline $1932-1933$ & - & - & - & - \\
\hline $1933-1934$ & 10 & - & - & - \\
\hline $1934-1935$ & - & - & - & - \\
\hline Toplam & 50 & 15 & - & - \\
\hline
\end{tabular}

80 Maarif 1928-34 Millet Mektepleri Faaliyet istatistiği, s. 41. 81 Maarif 1928-34 Millet Mektepleri Faaliyet Istatistiği, s. 41. 
Yukarıdaki tabloda görüldüğü üzere Sinop köylerinde 1928-1935 yılları arasında Millet Mektebi dışında açılan (B) dershanesi bulunmamaktadır. Bu durum özel (B) dershanelerine ilginin olmadığını göstermektedir. Sinop köylerinde sadece 1928-1929 ve 1933-1934 yılları arasında özel (A) dershanelerinin açılmış olduğunu görmekteyiz. (A) dershanesinin daha yoğun olduğu ayrıca burada ders alan erkeklerinde kadınlardan fazla olduğu gözlenmiştir. 1928-1935 yılları arasında Sinop köylerinde hiçbir erkek ve kadının (B) dershaneleri için dışarıdan özel ders almadığı da görülmektedir. Ayrıca 1929-1933 ve 1934-1935 yılları arasında özel (A) dershanelerinin de açılmadığı anlaşılmaktadır.

Harf İnkılâbı sonrasında okuma oranını arttırmak için yapılan girişimlerden biriside okuma odaları kurulmasıdır. Ancak Başvekâlet İstatistik Umum Müdürlüğünün hazırladığı "Maarif 1933-34 Halk Okuma Odaları ve Umumi Kütüphaneler Istatistiği" isimli rapora göre Sinop'ta böyle bir okuma odasının kurulmadığını görmekteyiz ${ }^{82}$. Ancak bunun nedeni olarakSinop'ta vilayet tarafından 1 adet, Halkevleri tarafından da 1 adet olmak üzere toplam 2 adet genel kütüphane kurulmasını gösterebiliriz ${ }^{83}$. Vilayetin Sinop'ta kurduğu Rıza Nur Kütüphanesinde hiçbir memur ve müstahdem çalışmamasına rağmen kütüphanenin bir yıllık tahsisatının 150 lira olduğu görülmektedir. Sinop Halkevi'nin kurduğu kütüphanede ise 1 erkek memur ve 1 müstahdem çalışmasından dolayı yıllık tahsisatın 751 lira olan yıllık tahsilâtın 650 lirasının maaşa gittiği de anlaşılmaktadır. Buna karşın kitaba harcanacak olan yıllık tahsisatın 60 lirasının da diğer masraflar olarak yazılmasından dolayı kitap alımına para kalmadığı gözlenmiştir ${ }^{84}$. Sinop Halkevi kütüphanesinin kitap sayısı ise $275^{\prime}$ tir $^{85}$. Sinop'taki kütüphanelerdeki kitap sayısının az olmasına karşın gerek Sinop Halkevi gerekse Rıza Nur Kütüphanesi sayesinde yeni harfleri öğrenen çeşitli meslek ve yaş gruplarındaki vatandaşların buralarda yoğun bir şekilde okuma yapması ${ }^{86}$ elde edilen başarıların meyvesini verdiğinin bir göstergesidir.

\section{SONUÇ}

Türkler çok çeşitli alfabeler kullanmakla birlikte en uzun süre kullandıkları alfabe Arap alfabesi olmuştur. Ancak bu alfabenin Türkçe okuma- yazmayı zorlaştırmasından dolayı özellikle Osmanlı Devleti'nin son dönemlerinde aydınlar tarafından değiştirilmek ya da daha kolay okunur hale getirmek için birtakım çalışmalar yapılmışsa da Kur'an-ı Kerim'in Arapça yazılmasından dolayı dini bir anlam yüklenerek değiştirilmesine karşı çıkılmıştır. Cumhuriyet döneminde ise 1926 da Azerbaycan'ın Latin harflerini kabul etmesi Türkiye'nin de buna benzer bir karar alabileceğini düşündürtmesine rağmen hem 1926'da Mustafa Kemal'e suikast düzenlenmesi hem de 1927'de Mustafa Kemal'in Nutuk'u okuması ve bu eserin birçok kişi tarafından da okunup anlaşılabilmesi için Arap harflerine ihtiyaç duyulması bu inkılâbın daha sonra gerçekleşmesine neden olmuştur. Ancak Mustafa Kemal, Harf İnkılâbı resmileşmeden hazırlıkların başlamasını sağlamış böylece süreç 1 Kasım 1928'de Harf İnkılâbı'nın kabulü ile 11 Kasım 1928'de de Millet Mektepleri Talimatnamesi'nin kabulü ile sonuçlanmıştır. Harf inkılâbının ardından ilk aşama olarak yeni Türk harflerini en kısa zamanda, mümkün mertebe en fazla vatandaşa öğretebilmek amacıyla Millet Mektepleri açılmıştır. Millet mektepleri; açılış tarihi olan 1 Ocak 1929 tarihinde Türkiye'nin pek çok bölgesinde, yaklaşık üç ay gibi kısa bir sürede teşkilatlanmasını tamamlayarak eğitim öğretim faaliyetlerine başlamıştır. Millet

82 Maarif 1933-34 Halk Okuma Odaları ve Umumi Kütüphaneler İstatistiği, Başvekâlet İstatistik Umum Müdürlüğü, Devlet Matbaası, İstanbul, 1935, s.3.

83 Maarif 1933-34 Halk Okuma Odaları ve Umumi Kütüphaneler İstatistiği, s. 37.

84 Maarif 1933-34 Halk Okuma Odaları ve Umumi Kütüphaneler İstatistiği, s. 39.

85 Maarif 1933-34 Halk Okuma Odaları ve Umumi Kütüphaneler İstatistiği, s. 44.

86 Maarif 1933-34 Halk Okuma Odaları ve Umumi Kütüphaneler İstatistiği, s. 55. 
Mekteplerinde amaç okuryazar en üstten en alta vatandaşları bilgili ve kültürlü olan bir toplum oluşturmaktı. Türk Harf inkılâbı ile sadece okuyup yazmayı yaygın hale getirmek amaçlanmamış ayrıca sosyal ve kültürel alanlarda da değişimler meydana getirmiştir.

Sinop özeline baktığımızda ise 28 Ekim 1927 tarihli genel nüfus sayımında Sinop halkının Arap harfleriyle okur-yazarlık durumunun da düşük olduğu görülmektedir. Buna göre Sinop 169.965 nüfusuyla diğer Buradaki rakamlara göre Sinop'ta 162.626 kişi okuma yazma bilmemekte olup sadece 7339 kişi okuma yazma bildiği anlaşılmaktadır. 1927 yılı genel nüfus sayımı verilerinden de anlaşıldığı üzere şehirde okuma-yazma bilen sayısının düşüklüğü görülmektedir. Bu nedenle harf inkılâbının Sinop şehri özelinde de gerekliliği anlaşılmaktadır. Bundan dolayı olsa gerek Gazi Mustafa Kemal, Edirne'den sonra Sinop'a gelerek harf inkılâbını anlatması önemli bir dönüm noktası olmuştur. Millet Mekteplerinin açılmasından sonra Sinop da ciddi bir okuma seferberliği başlatılmıştır. Bunun için her sene Millet Mektepleri açılmış olmasına rağmen hem şehirlerde hem de köylerde bu mekteplere ilginin fazla olmadığı anlaşılmıştır. Ancak her şeye rağmen bu mekteplerin hem (A) hem (B) dershanelerine erkeklerin kadınlardan daha fazla ilgi gösterdiği görülmüştür.

Millet Mekteplerinin Sinop'taki faaliyetlerine baktığımızda 1928-1935 yılları arasında merkezde 112 adet Millet Mektebi (A) dershanesi, 26 adet (B) dershanesi açılmıştır. Sinop'un köylerinde ise 230 adet (A) dershanesi, 9 adet (B) dershanesi açılmıştır. Bu durum nüfusun köylerde daha yoğun olduğunu ve buralarda okuryazarlık oranının daha düşük olduğunun da göstergesidir. Sinop genelindeki Millet Mekteplerinde toplamda 380 kadın ve erkek öğretmen görev almıştır. Ancak erkek katılımcıların daha fazla olmasından dolayı erkek öğretmen sayısı kadınlarınkinden daha fazladır. Millet Mektepleri (A) ve (B) dershanelerine Sinop merkezi ve köylerinde kayıt yaptıran 15568 (A) dershanesi öğrencisi, 2150 (B) dershanesi öğrencisi kayıt yaptırmıştır. Ancak 7354 kişi (A) dershanesi ve 1761 kişi (B) dershanesi derslerine devam ederek mezuniyet belgesi almaya hak kazanmıştır. Bunların dışında Sinop'ta özel dersler alarak (A) dershanesine katılım yapan 664, (B) dershanesine ise 150 kişi eğitim almıştır. Millet Mekteplerine ilginin en yoğun olduğu yıl şehir merkezinde 1928-1929 yılı iken köylerde mekteplere ilginin en yoğun olduğu yıl ise 1929-1930 olduğu anlaşılmıştır. Fakat bu yoğun ilginin olduğu yıllarda dahi (A) dershanesine olan ilginin (B) dershanesine olan ilgiden yüksek olduğu gözlenmiştir. Yine hem şehirlerde hem de köylerde dışarıdan özel ders alma ihtiyacının pek de tutulmadığı da çıkan sonuçlar arasında yer almıştır. Yine şehir ve köylerde (A) dershanesine ilginin (B) dershanesine oranla daha fazla olduğu gözlenmiştir. Bunun sebebi de Millet Mektepleri Talimatnamesinde yer alan memuriyet, devlet dairelerinde çeşitli işlere girebilmek, muhtar ya da mahalle/köy azası olabilmek için okuryazar olmanın yeterli olmasının etkisinin büyük olmasıdır. 1928-1935 yılları arasında Sinop'ta Millet Mektepleri dışında birçok devlet ve özel kurum, belediye, öğretmen, öğrenci, asker, polis ve şirketler ile kendi çabalarıyla öğrenen birçok kişi bu sayılara dâhil değildir. Dolayısıyla bunlar da dikkate alındığında Latin harfleriyle okuma yazma öğrenenlerin sayısı büyük oranda amacına ulaştığı anlaşılmaktadır. Sonuç olarak birkaç sene içerisinde okuma yazma bilmeyen kalmayacak sözünün Sinop açısından önemli ölçüde gerçekleştiğini söyleyebiliriz. 


\section{KAYNAKÇA}

\section{A. ARŞivLER}

Başbakanlık Cumhuriyet Arşivi (BCA). BCA, 490.1, 1.3.12, 22.09.1929, Ek 9. BCA, 490.1, 1.3.12, 22.09.1929, Ek 10. BCA, 490.1, 1.3.12, 22.09.1929, Ek 11. BCA, 490.1, 1.3.12, 22.09.1929, Ek 12. BCA, 490.1, 1.3.12, 22.09.1929, Ek 13. BCA, 490.1, 1.3.12, 22.09.1929, Ek 14. BCA, 490.1, 1.3.12, 22.09.1929, Ek 15. BCA, 490.1, 1.3.12, 22.09.1929, Ek 16. BCA, 490.1, 1.3.12, 22.09.1929, Ek 17. BCA, 490.1, 1.3.12, 22.09.1929, Ek 18. BCA, 490.1, 1.3.12, 22.09.1929, Ek 19. BCA, 490.1, 1.3.12, 22.09.1929, Ek 20. BCA, 490.1, 1.3.12, 22.09.1929, Ek 22. BCA, 490.1, 1.3.12, 22.09.1929, Ek 23. BCA, 490.1, 1.3.12, 22.09.1929, Ek 24. BCA, 490.1, 1.3.12, 22.09.1929, Ek 25. BCA, 490.1, 1.3.12, 22.09.1929, Ek 26. BCA, 490.1, 1.3.12, 22.09.1929, Ek 27. BCA, 490.1, 1.3.12, 22.09.1929, Ek 28. BCA, 490.1, 1.3.12, 22.09.1929, Ek 29. BCA, 490.1, 1.3.12, 22.09.1929, Ek 30. BCA, 490.1, 1.3.12, 22.09.1929, Ek 32. BCA, 490.1, 1.3.12, 22.09.1929, Ek 33. BCA, 490.1, 1.3.12, 22.09.1929, Ek 34.

\section{B. KITAPLAR}

28 Teşrinievvel 1927 Umumî Nüfus Tahriri: Usuller Kanun ve Talimatnameler Neticelerin Tahlili, III. Fasikül, Başvekâlet Müdevvenat Matbaası, Ankara, 1929.

Atatürk'ün Söylev ve Demeçleri (2006), Türk İnkılâp Tarihi Enstitüsü Yayınları, Ankara.

Ateş, Sinan, Yücel Namal ve Muhibbe Erdoğan (2019), Harf Inkılâbı ve Millet Mektepleri (1928- 1935): Zonguldak Örneği, Ötüken Yayınları, İstanbul.

Avcı, Orhan (2004), Irakta Türk Ordusu, Vadi Yayınları, Ankara.

Aydemir, Şevket Süreyya (1999), Tek Adam C.III, Remzi Kitabevi, İstanbul.

Başoğlu, Bekir (1978), Sinop ili Tarihi, Ayyıldız Matbaası, Ankara.

Harflerin Değişmesi Münasebetiyle Eski ve Yeni Harfler (1928), Ahmed Ihsan Matbaası, İstanbul.

Encümenin Harf ve Imla Üzere Yeni Türkçe Alfabe Yeni Türk Harfleri, Türk Neşriyat Yurdu, İstanbul 1928.

Ergin, Muharrem (1995), Orhun Abideleri, Boğaziçi Yayınları, İstanbul. 
Goloğlu, Mahmut (2006), Devrimler ve Tepkileri, Türkiye İş Bankası Kültür Yayınları, İstanbul, Şubat.

İlgürel, Mücteba (1981), “Millet Mektepleri”, Doğumunun 100. Yılında Atatürk'e Armağan (Ayrı Basım), Edebiyat Fakültesi Matbaası, İstanbul.

İnönü, İsmet (2014), Hatıralar, Yay. Haz. Sabahattin Selek, Bilgi Yayınevi, Ankara, Ağustos.

Kinross, Lord (1994), Atatürk: Bir Milletin Yeniden Doğuşu, Çev. Necdet Sander, Altın Kitaplar, İstanbul.

Maarif 1928-35 Millet Mektepleri Faaliyeti Istatistiği, Başvekalet İstatistik Umum Müdürlüğü, Hüsnütabiat Matbaası, İstanbul 1935.

Maarif 1933-34 Halk Okuma Odaları ve Umumi Kütüphaneler istatistiği, Başvekâlet İstatistik Umum Müdürlüğü, Devlet Matbaası, İstanbul 1935

Said, Mehmed (1338), Türkiye'nin Sıhhi İçtimai Coğrafyası: Sinob Sancağı, Ankara.

Özçelik, İsmail (1992), Milli Mücadele'de Güney Cephesi (Urfa), Kültür Bakanlığı Yayını, Ankara.

Özdemir, Coşkun (2007), Sinop’un Toplumsal Yapısı, İnönü Üniversitesi Basılmamış Yüksek Lisans Tezi, Malatya.

Öztoprak, İzzet (1989), Türk ve Batı Kamuoyunda Milli Mücadele, Türk Tarih Kurumu Yayınları, Ankara.

TBMM Zabıt Ceridesi(1340), Cilt: 6, Dönem: 2, Birleşim: 111, 25 Şubat, Ankara.

Tekin, Şinasi (1992), Türk Dünyası El Kitabı, Cilt: 2, Türk Kültürünü Araştırma Enstitüsü Yayınları, Ankara.

20 Illkteşrin 1935 Genel Nüfüs Sayımı: Kati ve Mufassal Neticeler: Sinop Vilayeti (1937), Cilt. 50, Türkiye Cumhuriyeti Başbakanlık İstatistik Genel Direktörlüğü, Hüsnütabiat Basımevi, İstanbul.

Türkiye Cumhuriyeti Devlet Salnamesi (1925-1926), Matbaa-i Amire, İstanbul 1926.

Türkiye Cumhuriyeti Devlet Salnamesi (1926-1927), Matbuat Müdüriyet Umumiyesi Neşriyatı: 2.

Ülkütaşır, M. Şakir (1991), Atatürk ve Harf Devrimi, Türk Dil Kurumu Yayınları, Ankara.

Yeni Harflerle Elifba Alfabe (1333), Matbaa-i Hayriye ve Şürekâsı, İstanbul.

\section{MAKALELER}

Ankara Doğu Araştırma Merkezi Eğitim Araştırma Grubu (1985), "Dil Encümeni Çalışmaları ve Latin Alfabesi Komisyonunun Modificatıons'u", Belgelerle Türk Tarihi Dergisi, Sayı. 9-10, Kasım-Aralık, s. 63-69.

Canbolat, Mustafa (1991), “Arap Yazılı Türk Alfabesinin Gelişmesi”, Harf Devriminin 50. Yılı Sempozyumu, Türk Tarih Kurumu yayınları, Ankara, s. 49-54.

Duman, Musa (2002), Yenileşme Dönemi Türk Dili", Türkler, Cilt. 15, Semih Ofset, Ankara, s. 107-130.

Erat, Muhammet (2002), "Osmanlıda Alfabe Tartışmaları", Türkler, Cilt. 15, Semih Ofset, Ankara, s. 154-166.

Henze, Paul (1985), “iç̧ Asya'da Siyaset ve Yazı”, Belgelerle Türk Tarihi Dergisi, Sayı: 9-10, Kasım-Aralık, s. 80-88.

Kınal, Füruzan (1969), "Çivi Yazısının Doğuşu ve Gelişmesi”, Tarih Araştırmaları Dergisi, Sayı: 12, s. 1. 
Köprülü, Fuad (1985), “Alfabe İnkılâbı”, Belgelerle Türk Tarihi Dergisi, Sayı. 9-10, KasımAralık, s. 31.

Levent, Agâh Sırrı (1985), "Latin Harfleri Meselesi”, Belgelerle Türk Tarihi Dergisi, Sayı. 9-10, Kasım-Aralık, s. 26-30.

Nerimanoğlu, Kamil Veli (2002), “Azerbaycan'da Devlet Dili Siyaseti”, Çev. Alesker Aleskerov, Türkler, Cilt. 19, Semih Ofset, Ankara, s. 244-251.

Okumuş, Ejder (2002), "Tanzimat'ın Dili", Türkler, Cilt. 15, Semih Ofset, Ankara, s. 139147.

Resmi Gazete (1928), Sayı: 1030, 3 Teşrinisani, s. 6001-6003.

Resmi Gazete (1928), Sayı: 900, 28 Mayıs, s. 5214-5215.

Şimşir, Bilal N (2006), "Amerikan Belgelerinde Türk Yazı Devrimi”, Türk Harf Devrimi Üzerine Incelemeler, Atatürk Araştırma Merkezi, Ankara, s. 1- 116.

Şirin, Hatice (2002), "Türklerde Alfabe ve Kimlik", Türkler, Cilt. 3, Semih Ofset, Ankara, s. 740-753.

Taneri, Aydın (1988), “Atatürk ve Harf İnkılâbı”, Milli Kültür, Sayı. 63, Aralık, s. 46-55.

Tangülü, Zafer, Oğuzhan Karadeniz ve Sinan Ateş (2014), "Cumhuriyet Dönemi Eğitim Sistemimizde Yabancı Uzman Raporları (1924- 1960), Turkish Studies- International Periodical For The Languages, Literature And History of Turkish or Turkic, Volume 9\5, Ankara, Spring, s. 1895-1910.

Uyguner, Muzaffer (1988), "Harf İnkılâbı Konusunda”, Milli Kültür, Sayı. 63, Aralık, s. 108109.

Ülkütaşır, M. Şakir (1971), “Anadolu Selçukluları Tarafından Sinop’un Muhasara ve Zaptı”, Türk Kültürü, Sayı. 106, Yıl: 9, Ağustos, s. 814- 819.

(1938), “Harf İnkılâbımıza Aid Bir Hatıra: Büyük Öğretmen Atatürk Halk İçin Başladıkları Alfabe Derslerinin Illkini Sinobda Vermişlerdi", Bartın, Yıl:15, Sayı: 666, 27 Teşrinievvel 1938, s. 2. 